Review Article

\title{
Biomarkers in Exhaled Breath Condensate and Serum of Chronic Obstructive Pulmonary Disease and Non-Small-Cell Lung Cancer
}

\author{
Mann Ying Lim ${ }^{1,2}$ and Paul S. Thomas ${ }^{1,2}$ \\ ${ }^{1}$ Inflammation and Infection Research Centre, Faculty of Medicine, University of New South Wales, Sydney, NSW 2031, Australia \\ ${ }^{2}$ Department of Respiratory Medicine, Prince of Wales Hospital, Randwick, Sydney, NSW 2031, Australia \\ Correspondence should be addressed to Paul S. Thomas; paul.thomas@unsw.edu.au
}

Received 22 April 2013; Accepted 8 July 2013

Academic Editor: Jin-Yuan Shih

Copyright ( $) 2013$ M. Y. Lim and P. S. Thomas. This is an open access article distributed under the Creative Commons Attribution License, which permits unrestricted use, distribution, and reproduction in any medium, provided the original work is properly cited.

Chronic obstructive pulmonary disease (COPD) and lung cancer are leading causes of deaths worldwide which are associated with chronic inflammation and oxidative stress. Lung cancer, in particular, has a very high mortality rate due to the characteristically late diagnosis. As such, identification of novel biomarkers which allow for early diagnosis of these diseases could improve outcome and survival rate. Markers of oxidative stress in exhaled breath condensate (EBC) are examples of potential diagnostic markers for both COPD and non-small-cell lung cancer (NSCLC). They may even be useful in monitoring treatment response. In the serum, S100A8, S100A9, and S100A12 of the S100 proteins are proinflammatory markers. They have been indicated in several inflammatory diseases and cancers including secondary metastasis into the lung. It is highly likely that they not only have the potential to be diagnostic biomarkers for NSCLC but also prognostic indicators and therapeutic targets.

\section{Introduction}

Chronic obstructive pulmonary disease (COPD) and lung cancer are the leading causes of deaths worldwide which are associated with cigarette smoking. COPD is a preventable and treatable disease characterised by progressive, irreversible airflow obstruction resulting from chronic airway inflammation [1-3]. It is responsible for $5.8 \%$ of all deaths (3.28 million deaths in 2008) and expected to become the third leading cause of death by 2030 [4]. Lung cancer, on the other hand, is defined as cancer which arises from cells of respiratory epithelium [5]. It has been the global leading cause of cancer death (approximately 1.8 million deaths per year) since 1985 [5], accounting for $12.4 \%$ of total new cancer cases diagnosed [5] and almost as many deaths as those from prostate, breast, and colon cancer combined [6]. The majority (85\%) of lung cancer is non-small-cell lung cancer (NSCLC), and it can be further divided into adenocarcinoma, squamous cell carcinoma, and large cell carcinoma comprising 38.5\%, 20\%, and $2.9 \%$ of all lung cancer cases, respectively [5].
Despite significant advances in 5-year survival rates of other cancers, that of lung cancer remains low at $15.6 \%$ (compared to $66 \%$ for colon cancer, $94 \%$ for melanoma, $90 \%$ for breast cancer, and $100 \%$ for prostate cancer) $[6,7]$. Even more disappointingly, $>52 \%$ of the patients have distant metastases (stage IV) at the time of diagnosis with a resultant 5 -year survival of $<3.6 \%$ (Figure 1) [5]. This is in stark contrast to the $60 \%-80 \% 5$-year survival rate for patients with stage I lung cancer [8]. Patients usually present late as lung cancer is silent early in its course of disease and the symptoms are often nonspecific, thereby mistakenly attributed to ageing or smoking [9]. Furthermore, screening procedures such as sputum cytology and chest X-rays have failed to decrease mortality $[10,11]$. Although screening CT scans increase the detection rate of early-stage lung cancer or small noncalcified nodules, the effect on mortality rate is still being evaluated, and the benefits need to be weighed against risks including radiation exposure, false positives, and overdiagnosis [12-16].

Much research has thus been directed towards the hope of finding new, simple, and minimally invasive biomarkers 


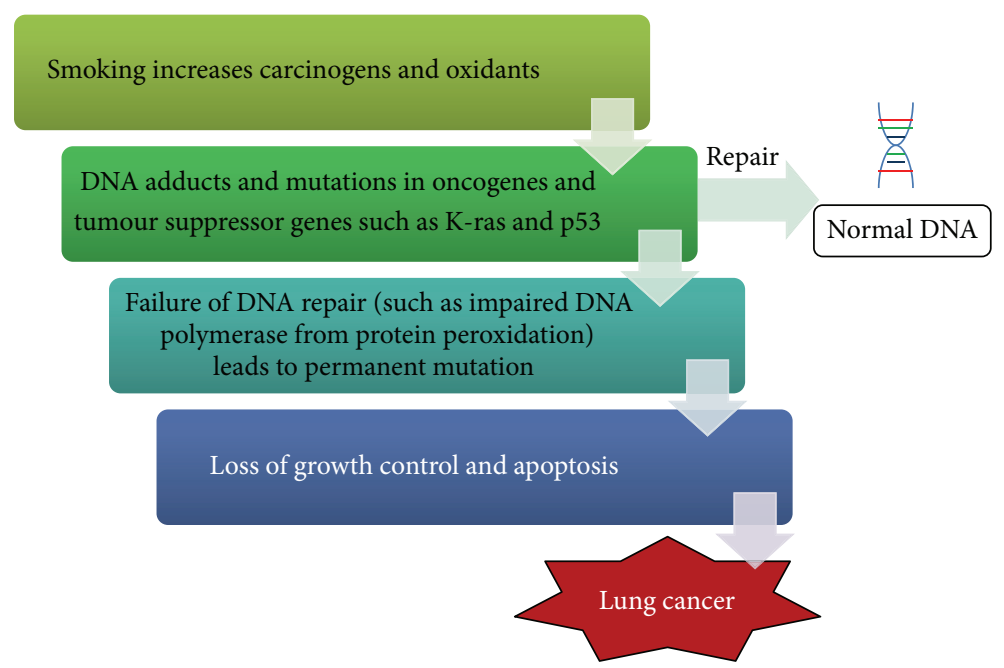

FIGURE 1: Stepwise progression towards lung cancer. Oxidants in cigarette smoking induce inflammation which subjects DNA to mutations. The failure to repair damaged DNA in critical coding regions causes cell proliferation and lung cancer.

of early diagnosis or screening for COPD and lung cancer. Exhaled breath condensate and serum samples are two such examples.

\section{Linking COPD and Lung Cancer}

It is well established that both COPD and lung cancer are usually due to tobacco smoking [17-22]. The majority (90\%) of lung cancers are associated with tobacco smoking [1], and smokers have a 2-30-fold increase in the risk of developing lung cancer $[21,23]$.

Apart from smoking, COPD is itself an independent risk factor $[5,7,18,24]$ which elevates the risk of lung cancer by 4.5 times $[1,7]$, and $1 \%$ of COPD patients develop lung cancer each year [18] while $40 \%-70 \%$ of lung cancer patients also have COPD $[19,22,25,26]$. Furthermore, a positive correlation exists between the extent of airflow limitation and incidence of lung cancer $[3,18]$. Even emphysema in never smokers (such as that of $\alpha$-antitrypsin deficient carriers) also carries an elevated risk of lung cancer by 2.4-fold [22].

It is also known that COPD patients are at increased risk of developing squamous cell carcinoma with a worse prognosis as they not only develop higher grade tumours but also suffer from a higher rate of recurrence $[1,18,27,28]$.

\section{Chronic Inflammation and Oxidative Stress}

COPD and lung cancer are both associated with chronic inflammation and oxidative stress, $[3,19,29,30]$ in which oxidants, inflammatory mediators, and antioxidants are key players.

3.1. Oxidants. Oxidants can be generated exogenously or endogenously. Exogenous sources of oxidants include tobacco smoke, infections, and pollutants (such as ozone and nitrogen dioxide) $[31,32]$. Of these sources, cigarette smoking is a major contributor as one puff contains up to $10^{15}$ oxidants particles and approximately 4700 different compounds [19, 31, 33]. Endogenously, oxidants are not only produced from the lung epithelial cells during respiration but also inflammatory mediators are released from cells such as neutrophils, eosinophils, and activated macrophages during inflammation [34-37]. They are generated through the mitochondrial electron transport chain during respiration and peroxidase enzymes such as myeloperoxidase (MPO), eosinophil peroxidase (EPO), and heme peroxidase during inflammation.

Under normal physiological conditions, oxidants have a role in growth regulation, intracellular signaling, and host defence (inflammation) against infection [38]. They comprise reactive oxygen species (ROS) or reactive nitrogen species (RNS). Examples of ROS include superoxide $\left({ }^{\circ} \mathrm{O}_{2}{ }^{-}\right)$, hydroxyl radicals $\left({ }^{\circ} \mathrm{OH}\right)$, and hydrogen peroxide $\left(\mathrm{H}_{2} \mathrm{O}_{2}\right)$ while RNS includes nitric oxide ( $\left.{ }^{\circ} \mathrm{NO}\right)$, nitrogen dioxide, and peroxynitrite $\left(\mathrm{ONOO}^{-}\right)$[32]. Superoxide can be dismutated to hydrogen peroxide. In the presence of redox-active transition metals such as iron or copper, highly unstable hydroxyl radical can be generated from hydrogen peroxide in a reaction known as the Fenton reaction. Meanwhile, nitric oxide readily reacts with $\mathrm{ROS}$ to form peroxynitrite which breaks down into nitrite $\left(\mathrm{NO}_{2}{ }^{-}\right)$and nitrate $\left(\mathrm{NO}_{3}{ }^{-}\right)$.

Reactive species are very unstable and potentially damaging as their unpaired electrons can exert injurious effects by oxidising DNA, proteins, and lipids [37, 39].

3.2. Inflammation and Oxidative Stress. The introduction of oxidants into the lung from tobacco smoking activates the innate immune cells such as lung epithelial cells whereby damage-associated molecular patterns (DAMPs) are released from injured cells [40]. Following this event, inflammation, which is the body's normal response to combat toxicants, is triggered [41-44] by the activation of transcription factor nuclear factor $-\kappa \mathrm{B}(\mathrm{NF}-\kappa \mathrm{B})$ and activator protein 1 (AP1) in airway epithelial cells and macrophages [29, 45]. 
The activated transcription factors are then responsible for the transcription of downstream inflammatory cytokines such as interleukin-6 (IL-6), interleukin-8 (IL-8), and tumour necrosis factor $\alpha$ (TNF- $\alpha)$ [34, 45-47]. The resultant elevated cytokine levels then attract more neutrophils and macrophages to augment inflammation (Figure 3) [29, 32, 45]. The degree of inflammation as evident by the infiltration of inflammatory cells correlates with disease severity $[1,19$, 29].

Following recruitment, neutrophils and macrophages release neutrophil elastase and matrix metalloproteinases9 which are proteases that degrade lung matrix elastin and collagen $[29,32,36,44]$. In addition, antiproteinases such as $\alpha$-1-protease-inhibitor ( $\alpha$-1-PI) and antileukoprotease [32] are inactivated by oxidants [34], leading to a proteinase/antiproteinase imbalance which destroys the alveolar wall, causing airspace enlargement (emphysema) in COPD (Figure 2) $[19,29]$.

In addition, injuries during inflammation also lead to goblet cell hyperplasia and squamous metaplasia. This impairs mucociliary clearance, and inflammatory mediators accumulate in the airways as a result, which again amplifies inflammation [1]. The activation of epithelial growth factor receptor (EGFR) in response to neutrophil elastase and oxidative stress is another reason for mucus hypersecretion [1].

Apart from initiating inflammation, oxidants also readily attack polyunsaturated fatty acids of cell membranes to form lipid peroxidation products (LPPs) such as hydroperoxides, endoperoxides, and aldehydes including ethane, pentane, isoprostanoids, malondialdehyde, and 4-hydroxy-2nonenal which are even more reactive [31,32, 46, 48]. Lipid peroxidation destroys cells by damaging cell membrane [31], and LPPs also react with DNA to cause genomic instability [48].

3.3. Oxidant/Antioxidant Disequilibrium. Under normal conditions, oxidants are counterbalanced by antioxidants which consist of enzymes (superoxide dismutase, catalase, glutathione peroxidase, and glutathione-S-transferase) and nonenzymatic free radical scavengers (glutathione, cysteine, thioredoxin, vitamins $\mathrm{C}$ and $\mathrm{E}$, beta-carotene, and uric acid) [46].

In response to elevated levels of oxidants, local antioxidants such as superoxide dismutase, catalase, glutathione associated enzymes, and manganese superoxide dismutase may increase in an attempt to counter the insult [49-51]. The continuous introduction of oxidants from smoking, however, persistently exposes the lung parenchyma to raised oxidant levels, causing chronic inflammation. This exhausts the buffering capacity of antioxidants, giving rise to an oxidant/anti-oxidant disequilibrium which leads to oxidative stress and cellular damage $[32,42,45,52]$.

3.4. Chronic Inflammation and DNA Damage. Chronic inflammation increases cell turnover and replication errors $[19,42,44,53-55]$. Replication errors which can occur include adduct formation, single or double stranded DNA breaks, promoter hypermethylation, sequence mutations, base insertions and deletions, translocations, microsatellite alterations, oncogene activation, and tumour suppressor gene inactivation $[1,46,48,56-59]$. For smokers with lung cancer, mutations commonly occur in the K-ras oncogene and p53 tumour suppressor genes as well as there being p16 promoter hypermethylation [60-65]. The DNA mutations may confer on the cells a survival advantage by allowing cells to escape from apoptosis thereby proliferating uncontrollably $[5,62$, 64].

Proofing mechanisms of DNA may attempt to repair or remove the damaged DNA via direct repair, double-strand break repair, cross-link repair, nucleotide excision, and base excision [1]. When damaged beyond repair, the cell usually undergoes apoptosis [5]. However, if any of the steps of reparation fail, or that damage to DNA is too extensive, permanent mutations may occur in the DNA, resulting in oncogenesis.

Apart from direct DNA damage, oxidants also promote tumorigenesis by direct reaction with proteins (protein peroxidation) to impair DNA reparative enzymes such as DNA polymerase [58].

\section{Exhaled Breath Condensate}

Exhaled breath condensate (EBC) is the cooling of exhaled gas to gain insight into the composition of extracellular lining fluid (ELF) and soluble exhaled gases [35, 66-68]. Compounds which have been measured include lipid peroxidation products, products of nitrogen oxide metabolism, hydrogen ions, hydrogen peroxide, cytokines, proteins, and DNA [6971].

EBC has several advantages as an investigational technique. It is noninvasive (unlike bronchoalveolar lavage), inexpensive, easy to collect, and also easily repeatable without causing airway inflammation or dysfunction (unlike bronchoalveolar lavage, transbronchial biopsy or induced sputum analysis) $[66,67,72,73]$. Furthermore, EBC collection devices are portable, do not induce any patient discomfort, and can thus be used in children and mechanically ventilated patients $[67,71,74-76]$.

$\mathrm{EBC}$ has the potential to be employed in the screening and diagnosis of COPD and lung cancer, disease phenotyping, exacerbations, and treatment response monitoring as well as disease severity measuring and prognosis indicating $[66,68$, $72,77]$. For instance, the use of EBC to measure lung antioxidant capacity could enable the monitoring of a response to antioxidant or anti-inflammatory treatment $[78,79]$. It may also allow early anti-inflammatory treatment before the development of symptoms and lung function decline in COPD $[78,79]$.

EBC, however, has a number of limitations which include dilution by water vapour, nonsite specificity, saliva contamination and variable reproducibility. With $>99.9 \%$ of EBC comprising water vapour [67], concentrations of the mediators of interest can sometimes be close to or below the detection limit of the appropriate assays; thus, assays of sufficient sensitivity are needed to effectively measure biomarkers in EBC $[71,77]$. There is currently no standardised assessment of EBC dilution, but such issues can in part be overcome by 


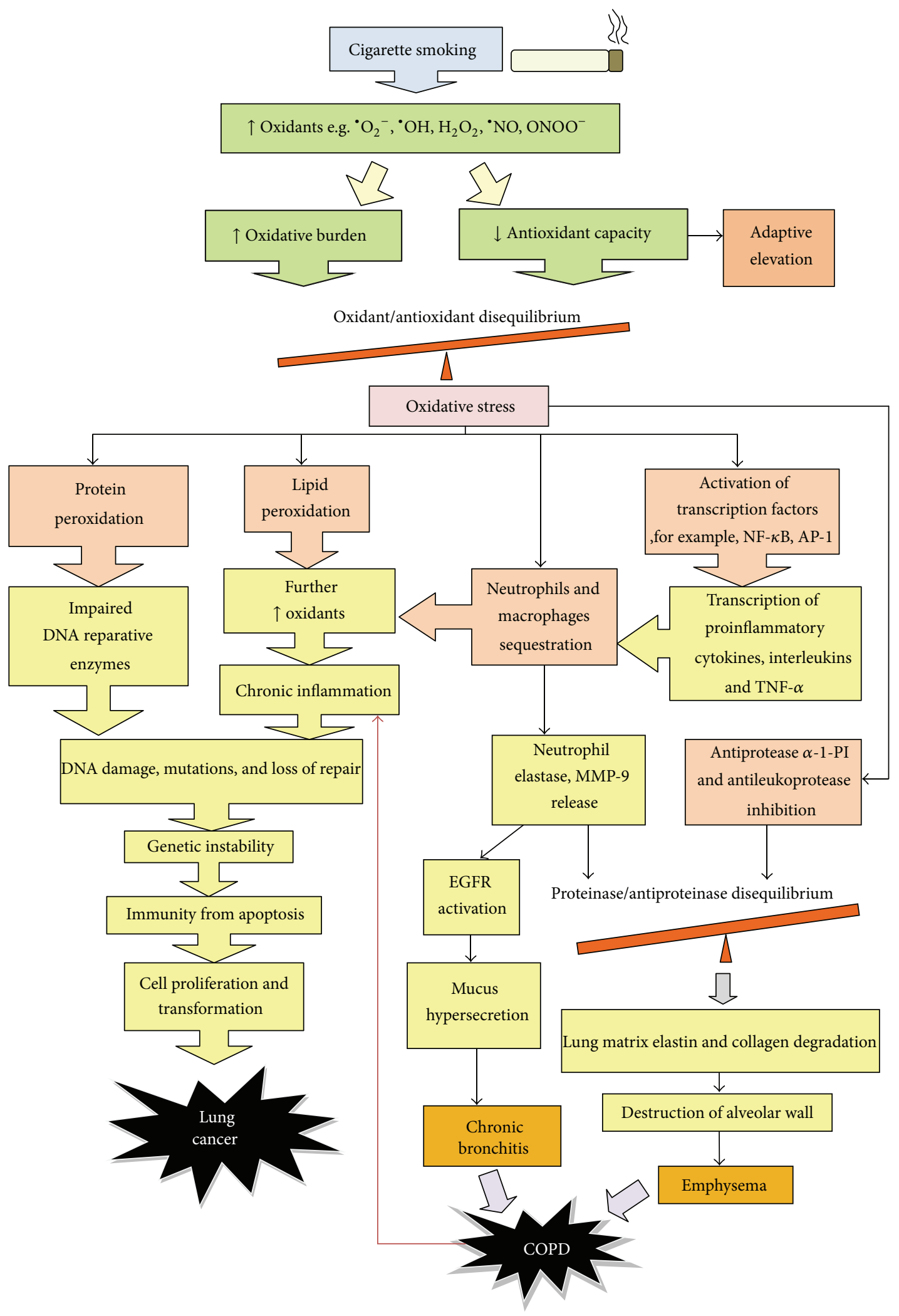

FIGURE 2: Smoking is the major cause of COPD and lung cancer. Oxidants in cigarette smoking are not only a direct cause of lung cancer by DNA damage through protein and lipid peroxidation but also an indirect cause by triggering inflammation. While products of recruited inflammatory mediators cause COPD by degrading lung matrix and promoting mucus hypersecretion, COPD is itself a disease of chronic inflammation which promotes tumorigenesis. 


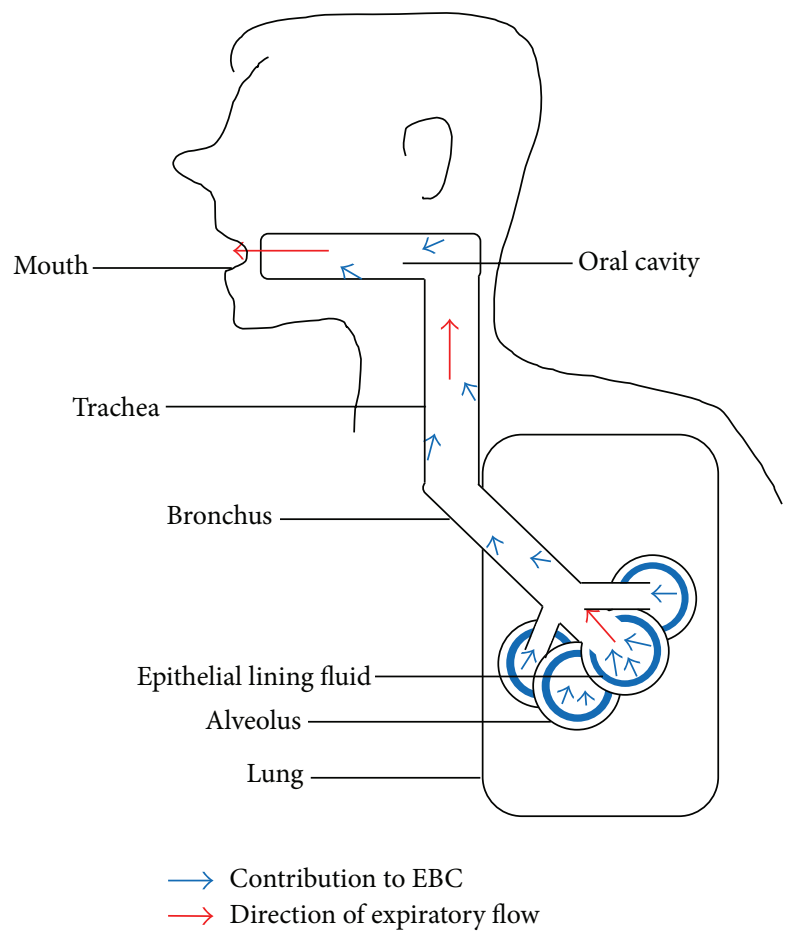

FIGURE 3: EBC consists of particles from ELF of alveoli, bronchi, and mouth, each with an unknown relative contribution.

correcting the dilution with urea, total protein, or cation concentration and conductivity of lyophilized EBC [71, 80, 81]. EBC dilution may also influence the $\mathrm{pH}$. It is thus important to deaerate the sample and monitor the dilution and buffering capacity of EBC when measuring $\mathrm{pH}$ [82].

As a result of the collection pathway, EBC also consists of nebulised fluid droplets from the alveoli, bronchi, and mouth, each with an unknown relative contribution (Figure 3 ). This nonsite specificity is a limitation, and it is inevitable that EBC of patients may consist of a fraction derived from areas not affected by the specific lung disease $[67,81]$. EBC from lung cancer patients, for instance, will consist of a large fraction derived from nonmalignant areas. As EBC is collected through the mouth, saliva contamination is another potential problem. It can, however, be minimised by asking subjects to rinse their mouth prior to collection, swallowing accumulated saliva where possible [67] and routinely testing for salivary amylase in EBC samples [71].

While the volume of EBC is reproducible, levels of biomarkers in EBC may vary, and this gives rise to problems in repeatability and reproducibility [71, 81, 83]. This can, however, be overcome by concentrating samples, using assays with a low limit of detection and high sensitivity in many cases [71].

A range of biomarkers have been studied in EBC of COPD and lung cancer patients. The results are as shown in Table 1.

\section{Plasma Proteomics}

In addition to EBC, the serum protein profile is another easily collected yet cost-effective tool in detecting and monitoring lung cancer $[9,84,85]$. Elevated levels of C-reactive protein, serum amyloid A (SAA), mucin I, and $\alpha$-I-antitrypsin can aid in distinguishing between healthy subjects or COPD patients [85] but are however low in sensitivity and/or specificity [86]. As such, novel markers are being described, such as the S100 proteins.

\section{S100 Proteins}

The S100 proteins are a family of more than 20 low molecular weight acidic proteins of $10-12 \mathrm{kDa}$ which are calciumbinding, and they belong to the EF hand proteins subfamily [87-92]. They consist of two EF-hands with different calcium binding affinities joined together by a central hinge region $[87,91,93]$. This explains their role in regulating calciumdependent intracellular processes [94] including protein phosphorylation, enzyme activity, cytoskeletal components, transcriptional factors, cell growth, and calcium homeostasis $[87,89,90]$. The S100 proteins can form homodimers, heterodimers, and oligomers with varying functions $[87,89,90]$. The majority of their coding genes are found on chromosome 1q21 which is frequently mutated [87, 95-97]. They have been implicated in many epithelial and soft tissue cancers including those of lung, breast, oesophagus, bladder, kidney, prostate, thyroid, gastric oral, colorectal, and liver [87, 9597].

6.1. S100A8 and S100A9. S100A8 is also known as calgranulin A or myeloid-related protein 8 while S100A9 is also known as calgranulin B or myeloid-related protein 14 . While much of the literature suggests that the S100A8 and S100A9 are proinflammatory, a body of research presents an opposing 
TABLE 1: Summary of EBC markers of oxidative stress and antioxidant capacity including S100 proteins in COPD and lung cancer (legend:

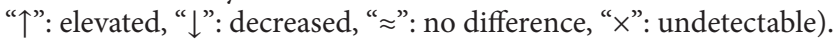

\begin{tabular}{|c|c|c|c|c|c|}
\hline \multirow{2}{*}{ Category } & \multirow{2}{*}{ Biomarkers } & \multicolumn{2}{|c|}{ COPD patients } & \multicolumn{2}{|c|}{ Lung cancer patients } \\
\hline & & $\begin{array}{l}\text { EBC (compared to } \\
\text { healthy volunteers) }\end{array}$ & $\begin{array}{l}\text { EBC (compared to } \\
\text { smokers or } \\
\text { ex-smokers) }\end{array}$ & $\begin{array}{l}\text { EBC (compared to } \\
\text { healthy volunteers) }\end{array}$ & $\begin{array}{l}\text { EBC (compared to } \\
\text { specific controls) }\end{array}$ \\
\hline \multicolumn{6}{|c|}{ Markers of oxidative stress } \\
\hline Reactive oxygen species & Hydrogen peroxide & $\uparrow[34,135-138]$ & $\uparrow[34]$ & $\uparrow[135]$ & \\
\hline \multirow{5}{*}{ Reactive nitrogen species } & Nitric oxide & $\uparrow[139-144]$ & $\uparrow[139,141]$ & $\uparrow[140]$ & $\begin{array}{l}\uparrow(\text { controls = cancer } \\
\text { patients })[142]\end{array}$ \\
\hline & Nitrite & $\uparrow[145]$ & $\uparrow[145]$ & & $\begin{array}{l}\uparrow(\text { controls }=\text { cancer } \\
\text { patients) }[142]\end{array}$ \\
\hline & Nitrate & $\begin{array}{l}\text { High variability } \\
{[146]}\end{array}$ & & & $\begin{array}{l}\downarrow \text { (controls = cancer } \\
\text { patients) [142] }\end{array}$ \\
\hline & & $\approx[141,147]$ & & & \\
\hline & Peroxynitrite & $\uparrow[148,149]$ & $\uparrow[148,149]$ & & \\
\hline \multirow{11}{*}{$\begin{array}{l}\text { Lipid peroxidation } \\
\text { products/eicosanoids } \\
\text { (arachidonic acid } \\
\text { derivatives) }\end{array}$} & 8-isoprostane & $\uparrow[137,148,150,151]$ & $\uparrow[34,148,150]$ & & $\begin{array}{l}\uparrow[135] \\
\approx(\text { controls = healthy } \\
\text { smokers })[152]\end{array}$ \\
\hline & Malondialdehyde & $\uparrow[138,153]$ & $\uparrow[153]$ & $\uparrow[154]$ & \\
\hline & 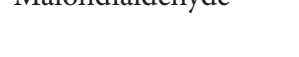 & $\approx[137,155]$ & $\approx[137]$ & | & \\
\hline & Leukotrienes $\mathrm{B}_{4}$ & $\uparrow[156-158]$ & $\uparrow[159]$ & & $\begin{array}{l}\uparrow(\text { controls }=\text { patients } \\
\text { without pulmonary } \\
\text { disease })[156]\end{array}$ \\
\hline & Leukotriene C4 & & & $\uparrow[160]$ & \\
\hline & Leukotriene D4 & & & $\uparrow[160]$ & \\
\hline & Leukotriene E4 & $\approx[158]$ & & $\uparrow[160]$ & \\
\hline & Prostaglandin $\mathrm{E}_{2}$ & $\uparrow[158]$ & & & \\
\hline & $\begin{array}{l}\text { Thromboxane B2 (the } \\
\text { stable form of } \\
\text { thromboxane A2) }\end{array}$ & $\downarrow[158]$ & & & \\
\hline & $\begin{array}{l}\text { Prostaglandin } \\
\text { D2-methoxime }\end{array}$ & $\approx[158]$ & & & \\
\hline & Prostaglandin F2 $\alpha$ & $\uparrow[158]$ & & & \\
\hline \multirow{7}{*}{ Cytokines and proteins } & $\begin{array}{l}\text { Tumour necrosis } \\
\text { Factor- } \alpha\end{array}$ & $\approx[47]$ & & $\uparrow[161]$ & $\begin{array}{l}\uparrow(\text { controls }=\text { smokers } \\
\text { without COPD or } \\
\text { lung cancer })[152]\end{array}$ \\
\hline & Interleukin-6 & $\begin{array}{l}\uparrow[162] \\
\approx[47]\end{array}$ & & $\uparrow[163]$ & \\
\hline & Interleukin-8 & $\approx[47,164]$ & $\approx[164]$ & & $\begin{array}{l}\uparrow(\text { controls }=\text { patients } \\
\text { without pulmonary } \\
\text { diseases })[156]\end{array}$ \\
\hline & Metaloproteinase- 9 & & $\uparrow[134]$ & & $\begin{array}{l}\uparrow(\text { controls }=\text { patients } \\
\text { without pulmonary } \\
\text { diseases })[165]\end{array}$ \\
\hline & $\begin{array}{l}\text { Vascular endothelial } \\
\text { growth factor }\end{array}$ & & & & $\begin{array}{l}\uparrow(\text { controls }=\text { healthy } \\
\text { smokers) }[152]\end{array}$ \\
\hline & Endothelin-1 & $\uparrow[166]$ & & $\uparrow[167]$ & \\
\hline & & & & $\uparrow[168]$ & \\
\hline $\begin{array}{l}\text { Volatile organic } \\
\text { compounds }\end{array}$ & $\begin{array}{l}\text { Alkanes, alkane } \\
\text { derivatives, benzene } \\
\text { derivatives }\end{array}$ & $\begin{array}{c}\uparrow(\text { exhaled ethane) } \\
{[169]}\end{array}$ & & $\uparrow[170,171]$ & \\
\hline Heme breakdown product & Carbon monoxide & $\uparrow[144]$ & $\uparrow[144]$ & & \\
\hline $\mathrm{pH}$ & & $\downarrow[164,172-175]$ & $\approx[173]$ & $\approx[172]$ & \\
\hline
\end{tabular}


TABle 1: Continued.

\begin{tabular}{|c|c|c|c|c|c|}
\hline \multirow{2}{*}{ Category } & \multirow{2}{*}{ Biomarkers } & \multicolumn{2}{|c|}{ COPD patients } & \multicolumn{2}{|c|}{ Lung cancer patients } \\
\hline & & $\begin{array}{l}\text { EBC (compared to } \\
\text { healthy volunteers) }\end{array}$ & $\begin{array}{c}\text { EBC (compared to } \\
\text { smokers or } \\
\text { ex-smokers) }\end{array}$ & $\begin{array}{l}\text { EBC (compared to } \\
\text { healthy volunteers) }\end{array}$ & $\begin{array}{l}\text { EBC (compared to } \\
\text { specific controls) }\end{array}$ \\
\hline \multirow{6}{*}{$\begin{array}{l}\text { Deoxyribonucleic acid } \\
\text { mutations }\end{array}$} & $\begin{array}{l}\text { 3p microsatellite } \\
\text { alterations }\end{array}$ & & & $\uparrow[176]$ & \\
\hline & $\begin{array}{l}\text { Tumour suppressor } \\
\text { gene P53 mutations }\end{array}$ & & & $\uparrow[177]$ & \\
\hline & Oncogene KRAS & & & $\uparrow[178]$ & \\
\hline & $\begin{array}{l}\text { Epidermal growth } \\
\text { factor receptor } \\
\text { (EGFR) gene } \\
\text { mutations }\end{array}$ & & & $\begin{array}{c}\uparrow \text { (in small number } \\
\text { of heavy smokers } \\
\text { with squamous cell } \\
\text { carcinoma) [179] }\end{array}$ & \\
\hline & $\begin{array}{l}\text { Gene promoter } \\
\text { methylation } \\
\text { mutations }\end{array}$ & & & $\uparrow[180]$ & \\
\hline & $\begin{array}{l}\text { Mitochondrial DNA } \\
\text { mutations }\end{array}$ & & & & $\begin{array}{l}\uparrow(\text { controls }=\text { smokers, } \\
\text { exsmokers without } \\
\text { chronic respiratory } \\
\text { diseases, respiratory } \\
\text { illnesses, or lung } \\
\text { cancer) [70] }\end{array}$ \\
\hline Viruses & $\begin{array}{l}\text { Human papilloma } \\
\text { virus }\end{array}$ & & & & $\begin{array}{l}\uparrow(\text { controls = patients } \\
\text { suspected of lung } \\
\text { cancer but with } \\
\text { negative cytology) } \\
{[181]}\end{array}$ \\
\hline \multicolumn{6}{|c|}{ Markers measuring antioxidant capacity } \\
\hline Enzymes & Superoxide dismutase & & & & $\begin{array}{l}\uparrow(\text { controls = patients } \\
\text { without pulmonary } \\
\text { diseases) }[182]\end{array}$ \\
\hline \multirow[t]{4}{*}{ Nonenzymatic antioxidants } & $\begin{array}{l}\text { Ascorbic acid/vitamin } \\
\text { C }\end{array}$ & & & $\begin{array}{c}\downarrow(\uparrow \text { in percentage } \\
\text { degrada- } \\
\text { tion/oxidation } \\
\text { rate) }[161]\end{array}$ & \\
\hline & Urate & $\times[175]$ & $\times[175]$ & & \\
\hline & Ferritin & & & & $\begin{array}{l}\uparrow(\text { controls }=\text { patients } \\
\text { affected by } \\
\text { transudative pleural } \\
\text { effusion and without } \\
\text { pulmonary diseases) } \\
{[182]}\end{array}$ \\
\hline & Bilirubin & $\approx[175]$ & $\approx[175]$ & & \\
\hline
\end{tabular}

view. It is possible that the opposing effects of the calgranulins are concentration dependent, being proinflammatory at low concentrations and anti-inflammatory at high concentrations $[98,99]$.

A100A8 and S100A9 are believed to be anti-inflammatory by being preferentially oxidized, thereby scavenging ROS/ RNS. Oxidative modifications by ROS/RNS and posttranslational modifications such as S-nitrosylation and S-glutathionylation are proposed to be the regulatory switches which activate such anti-inflammatory properties $[98,99]$.
Calgranulins S100A8 and S100A9, however, are also believed to play a role in inflammation by acting as chemokines for neutrophils and monocytes [88, 91, 100-102]. They reportedly bind to the receptor for advanced glycation end products (RAGE) and toll-like receptor-4 (TLR4) [88, $90,103,104]$. This binding activates the NF- $\kappa \mathrm{B}$ transcription pathway, subsequent generation of downstream proinflammatory cytokines, and recruitment of inflammatory mediators such as neutrophils and monocytes in a positive feedback loop (Figure 4) [90, 103, 104]. As such, the S100 proteins have implicated many inflammation-related diseases 


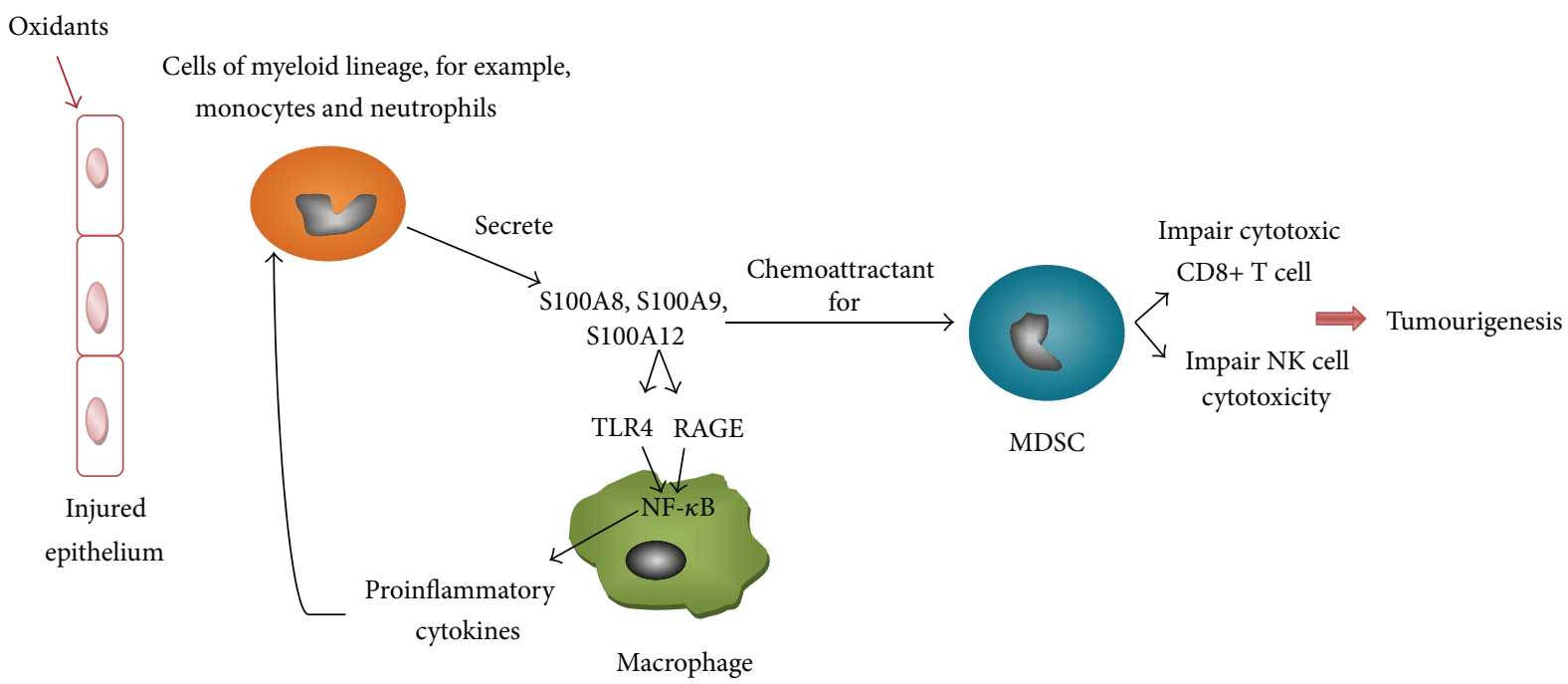

FIGURE 4: The calgranulins, S100A8, S100A9, and S100A12, are secreted by cells of the myeloid lineage such as neutrophils and monocytes. They bind to TLR4 and RAGE on macrophages and activate the NF- $\kappa$ B signalling pathway which leads to the production of proinflammatory cytokines. The production of proinflammatory cytokines then provides a positive feedback by promoting the recruitment of more neutrophils and monocytes. S100A8 and S100A9 are also chemoattractants for MDSCs. MDSCs which move from bone marrow to peripheral blood cause immune suppression and enhance tumourigenesis by impairing cytotoxic CD8+ T cell and NK cell cytotoxicity.

including rheumatoid arthritis, juvenile idiopathic arthritis, cystic fibrosis, and chronic inflammatory bowel disease [88, 91, 93, 105-107]. Levels of S100A8 and S100A9 are elevated in the bronchoalveolar fluid of COPD patients compared to smokers, which suggest a potential as diagnostic markers of COPD [108]. Another study comparing acute respiratory distress syndrome (ARDS), cystic fibrosis (CF), and COPD suggests that S100A8 and S100A9 are linked to chronic inflammation while S100A12 is linked to acute inflammation [109].

Apart from playing a role in inflammation which promotes tumourigenesis (inflammation-induced cancer) [55], the S100 proteins are also capable of modulating host immune response to promote tumour progression [87].

S100A8 and S100A9 are expressed by cells of myeloid origin, making up $40 \%-50 \%$ of their cytosolic content. Cells expressing S100A8 and S100A9 include granulocytes (e.g., neutrophils), monocytes, and early differentiation stages of macrophages $[88,93,95,97,106,110]$. S100A12 is however only expressed in neutrophils $[102,111]$. S100A8 and S100A9 predominantly function as heterodimer complex S100A8/A9 which is also known as calprotectin $[88,112]$. Calprotectin is released by neutrophils and activated by monocytes, tumour cells, and myeloid-derived suppressor cells (MDSCs) [113]. It functions to regulate inflammation and inhibit myeloid cell differentiation [114].

MDSCs are precursors of macrophages, granulocytes, and dendritic cells [113] which increase in number during inflammation, cancer, and infection [115]. They suppress natural killer $\mathrm{CD} 4+$ and $\mathrm{CD} 8+\mathrm{T}$ cell immunity against cancer by inhibiting dendritic cell differentiation to compromise antigen presentation (Figure 4) [112, 115-120]. MDSCs suppress this innate immunity through the induction of FOXP3 + T regulatory cells by secreting interleukin-10 (IL10), interferon-gamma (IFN- $\gamma$ ) and high levels of ROS, peroxynitrite, and nitric oxide [116].

In tumorigenesis, MDSCs are attracted from bone marrow to peripheral blood by inflammatory cytokines (e.g., interleukin- $1 \beta$, interleukin- 6 , prostaglandin $\mathrm{E}_{2}$ ), chemokines, tumour-derived growth factors, and myeloid-related proteins such as S100A9 and S100A8 [116, 117]. The production of proinflammatory S100A8/9 then sustains MDSC accumulation by an autocrine feedback through TLR4 and RAGE which activates the NF- $\kappa \mathrm{B}$ pathway and mitogenactivated protein kinase [113, 116, 117, 121]. Hence, similar to the positive feedback loop of oxidants, S100A8/A9 which is released by myeloid cells also promotes the recruitment of yet more leukocytes $[122,123]$.

S100A8/A9-positive myeloid cells are not only early infiltrating cells in the inflammatory process [97] but are also upregulated in epithelial malignancies including that of the prostate $[124,125]$, gastric [126], colon, and rectum $[127,128]$. As such, S100A9 is suggested to be a potential marker in differentiating prostate cancer from benign prostate hyperplasia or healthy controls [125].

In lung cancer, a recent study found that the expression of S100A8 and S100A9 is increased in patients with NSCLC [116]. NSCLC patients with an overexpression of S100A9 are usually associated with poorly differentiated tumours $[129,130]$, lower 5-year survival rate [108], and higher rate 
of relapse [129]. Moreover, S100A9 in CD11b+CD14+ monocytic MDSC correlates with tumour response to platinumbased chemotherapy with low CD11b+CD14+S100A9+ having longer progression-free survival [116]. These suggest the possibility of S100A8 and S100A9 as prognostic markers of NSCLC.

Lastly, S100A8 and S100A9 also play a role in cell proliferation and metastasis of primary tumours into the lung [87]. Their expression is increased in pulmonary myeloid and endothelial cells through the production of vascular endothelial growth factor-A, transforming growth factor- $\beta$, and TNF$\alpha$ by primary tumours before metastasis occurs $[87,131,132]$. S100A8 and S100A9 not only promote the recruitment of CD11b+ myeloid cells but also act as chemoattractants which draw tumour cells to premetastatic sites in the lungs [87, 110]. They recruit CD11b+ myeloid cells by activating p38 mitogen-activated protein kinase (MAPK) which promotes migration [110]. SAA3, which is induced by S100A8, interacts with TLR4 to stimulate the NF- $\kappa$ B pathway in promoting CD11b+ myeloid cell accumulation [110, 133]. In addition, S100A8 and S100A9 also increase cancer cell motility through p38-mediated activation of pseudopodia $[87,131]$. This makes S100A8/A9 a potential target for inhibiting lung metastasis.

\section{Future Directions}

Early Diagnosis, Predicting Prognosis, and Personalised Medicine. $\mathrm{EBC}$ and serum are noninvasive and minimally invasive techniques which are cost effective and easily sampled. If EBC markers of oxidative stress and serum proinflammatory S100 proteins or other candidate entities are diagnostic for COPD and NSCLC, it could greatly improve survival outcome by allowing early diagnosis and thus treatment.

As many NSCLC patients do not behave as predicted based on tumour staging, new markers are also needed to more accurately predict prognosis [134]. Prognostic biomarkers indicative of metastatic potential, response to treatment, and patient survival could aid in deciding treatments. For example, using $\mathrm{CD} 11 \mathrm{~b}+\mathrm{CD} 14+\mathrm{S} 100 \mathrm{~A} 9+$ to predict response to chemotherapy could be used to decide if patients should be given adjuvant or neoadjuvant chemotherapy or any chemotherapy at all.

Furthermore, it will be beneficial to discover more specific and sensitive serum biomarkers for lung cancer as well as to personalise anticancer therapies. For instance, knowing the reduced overall survival of patients with an overexpression of S100A9 may not only identify patients who are at high risk of a poor outcome [134] but also allow the administration of personalised anticancer therapy which targets S100A9 specifically to optimise outcome [64].

The S100 proteins have a great potential to be the new diagnostic tumour markers, prognostic predictor, and possibly therapeutic targets for NSCLC.

\section{Conflict of Interests}

The authors do not have any financial conflict of interests related to this paper.

\section{References}

[1] I. M. Adcock, G. Caramori, and P. J. Barnes, "Chronic Obstructive pulmonary disease and lung cancer: new molecular insights," Respiration, vol. 81, no. 4, pp. 265-284, 2011.

[2] K. F. Rabe, S. Hurd, A. Anzueto et al., "Global strategy for the diagnosis, management, and prevention of chronic obstructive pulmonary disease: GOLD executive summary," American Journal of Respiratory and Critical Care Medicine, vol. 176, no. 6, pp. 532-555, 2007.

[3] I. A. Yang, V. Relan, C. M. Wright et al., "Common pathogenic mechanisms and pathways in the development of COPD and lung cancer," Expert Opinion on Therapeutic Targets, vol. 15, no. 4, pp. 439-456, 2011.

[4] WHO, "Chronic Obstructive Pulmonary Disease (COPD)," 2013, http://www.who.int/respiratory/copd/en/index.html.

[5] C. S. D. Cruz, L. T. Tanoue, and R. A. Matthay, "Lung cancer: epidemiology, etiology, and prevention," Clinics in Chest Medicine, vol. 32, no. 4, pp. 605-644, 2011.

[6] R. Siegel, E. Ward, O. Brawley, and A. Jemal, "Cancer statistics, 2011: the impact of eliminating socioeconomic and racial disparities on premature cancer deaths," CA Cancer Journal for Clinicians, vol. 61, no. 4, pp. 212-236, 2011.

[7] R. P. Young and R. J. Hopkins, "How the genetics of lung cancer may overlap with COPD," Respirology, vol. 16, no. 7, pp. 10471055, 2011.

[8] L. Dominioni, A. Imperatori, F. Rovera, A. Ochetti, G. Torrigiotti, and M. Paolucci, "Stage I nonsmall cell lung carcinoma: analysis of survival and implications for screening," Cancer, vol. 89, no. 11, supplement, pp. 2334-2344, 2000.

[9] A. Amann, M. Corradi, P. Mazzone, and A. Mutti, "Lung cancer biomarkers in exhaled breath," Expert Review of Molecular Diagnostics, vol. 11, no. 2, pp. 207-217, 2011.

[10] E. F. Patz, P. C. Goodman, and G. Bepler, "Screening for lung cancer," The New England Journal of Medicine, vol. 343, no. 22, pp. 1627-1633, 2000.

[11] S. Sone, T. Nakayama, T. Honda et al., "Long-term follow-up study of a population-based 1996-1998 mass screening programme for lung cancer using mobile low-dose spiral computed tomography," Lung Cancer, vol. 58, no. 3, pp. 329-341, 2007.

[12] D. R. Aberle, F. Abtin, and K. Brown, "Computed tomography screening for lung cancer: has it finally arrived? implications of the national lung screening trial," Journal of Clinical Oncology, vol. 31, no. 8, pp. 1002-1008, 2013.

[13] L. Paleari, P. Granone, A. Cesario, and P. Russo, "Computed tomography screening for lung cancer: review of screening principles and update on current status," Cancer, vol. 112, no. 11, pp. 2520-2521, 2008.

[14] S. Senan, M. A. Paul, and F. J. Lagerwaard, “Treatment of earlystage lung cancer detected by screening: surgery or stereotactic ablative radiotherapy?" The Lancet Oncology, vol. 14, no. 7, pp. e270-e274, 2013.

[15] C. I. Henschke, "Early lung cancer action project: overall design and findings from baseline screening," Cancer, vol. 89, no. 11, supplement, pp. 2474-2482, 2000.

[16] P. B. Bach, J. R. Jett, U. Pastorino, M. S. Tockman, S. J. Swensen, and C. B. Begg, "Computed tomography screening and lung cancer outcomes," Journal of the American Medical Association, vol. 297, no. 9, pp. 953-961, 2007.

[17] D. M. Skillrud, K. P. Offord, and D. W. Miller, "Higher risk of lung cancer in chronic obstructive pulmonary disease. A 
prospective, matched, controlled study," Annals of Internal Medicine, vol. 105, no. 4, pp. 503-507, 1986.

[18] Y. Sekine, H. Katsura, E. Koh, K. Hiroshima, and T. Fujisawa, "Early detection of COPD is important for lung cancer surveillance," European Respiratory Journal, vol. 39, no. 5, pp. 12301240, 2012.

[19] H. Yao and I. Rahman, "Current concepts on the role of inflammation in COPD and lung cancer," Current Opinion in Pharmacology, vol. 9, no. 4, pp. 375-383, 2009.

[20] M. S. Tockman, N. R. Anthonisen, and E. C. Wright, "Airways obstruction and the risk for lung cancer," Annals of Internal Medicine, vol. 106, no. 4, pp. 512-518, 1987.

[21] J. Koshiol, M. Rotunno, D. Consonni et al., "Chronic obstructive pulmonary disease and altered risk of lung cancer in a population-based case-control study," PLoS One, vol. 4, no. 10, Article ID e7380, 2009.

[22] M. C. Turner, Y. Chen, D. Krewski, E. E. Calle, and M. J. Thun, "Chronic obstructive pulmonary disease is associated with lung cancer mortality in a prospective study of never smokers," American Journal of Respiratory and Critical Care Medicine, vol. 176, no. 3, pp. 285-290, 2007.

[23] M. E. Mattson, E. S. Pollack, and J. W. Cullen, "What are the odds that smoking will kill you?" American Journal of Public Health, vol. 77, no. 4, pp. 425-431, 1987.

[24] D. M. Mannino, S. M. Aguayo, T. L. Petty, and S. C. Redd, "Low lung function and incident lung cancer in the United States: data from the First National Health and Nutrition Examination Survey follow-up," Archives of Internal Medicine, vol. 163, no. 12, pp. 1475-1480, 2003.

[25] R. S. Loganathan, D. E. Stover, W. Shi, and E. Venkatraman, "Prevalence of COPD in women compared to men around the time of diagnosis of primary lung cancer," Chest, vol. 129, no. 5, pp. 1305-1312, 2006.

[26] J. Congleton and M. F. Muers, "The incidence of airflow obstruction in bronchial carcinoma, its relation to breathlessness, and response to bronchodilator therapy," Respiratory Medicine, vol. 89, no. 4, pp. 291-296, 1995.

[27] A. Papi, G. Casoni, G. Caramori et al., "COPD increases the risk of squamous histological subtype in smokers who develop nonsmall cell lung carcinoma," Thorax, vol. 59, no. 8, pp. 679-681, 2004.

[28] B. M. Smith, K. Schwartzman, B. Kovacina et al., "Lung cancer histologies associated with emphysema on computed tomography," Lung Cancer, vol. 76, no. 1, pp. 61-66, 2012.

[29] P. J. Barnes, "Immunology of asthma and chronic obstructive pulmonary disease," Nature Reviews Immunology, vol. 8, no. 3, pp. 183-192, 2008.

[30] A. Punturieri, E. Szabo, T. L. Croxton, S. D. Shapiro, and S. M. Dubinett, "Lung cancer and chronic obstructive pulmonary disease: needs and opportunities for integrated research," Journal of the National Cancer Institute, vol. 101, no. 8, pp. 554-559, 2009.

[31] L. Nagorni-Obradović, D. Pesut, V. Skodrić-Trifunović, and T. Adzić, "Influence of tobacco smoke on the appearance of oxidative stress in patients with lung cancer and chronic obstructive pulmonary diseases," Vojnosanitetski Pregled, vol. 63, no. 10, pp. 893-895, 2006.

[32] I. Rahman and W. MacNee, "Role of oxidants/antioxidants in smoking-induced lung diseases," Free Radical Biology and Medicine, vol. 21, no. 5, pp. 669-681, 1996.

[33] W. A. Pryor and K. Stone, "Oxidants in cigarette smoke: radicals, hydrogen peroxide, peroxynitrate, and peroxynitrite," Annals of the New York Academy of Sciences, vol. 686, pp. 12-28, 1993.
[34] K. Kostikas, G. Papatheodorou, K. Psathakis, P. Panagou, and S. Loukides, "Oxidative stress in expired breath condensate of patients with COPD," Chest, vol. 124, no. 4, pp. 1373-1380, 2003.

[35] N. Louhelainen, M. Myllärniemi, I. Rahman, and V. L. Kinnula, "Airway biomarkers of the oxidant burden in asthma and chronic obstructive pulmonary disease: current and future perspectives," International Journal of COPD, vol. 3, no. 4, pp. 585603, 2008.

[36] C. A. Owen, "Proteinases and oxidants as targets in the treatment of chronic obstructive pulmonary disease," Proceedings of the American Thoracic Society, vol. 2, no. 4, pp. 373-385, 2005.

[37] I. Rahman, S. K. Biswas, and A. Kode, "Oxidant and antioxidant balance in the airways and airway diseases," European Journal of Pharmacology, vol. 533, no. 1-3, pp. 222-239, 2006.

[38] H. Sauer, M. Wartenberg, and J. Hescheler, "Reactive oxygen species as intracellular messengers during cell growth and differentiation," Cellular Physiology and Biochemistry, vol. 11, no. 4, pp. 173-186, 2001.

[39] K. Garber, "A radical treatment," Nature, vol. 489, no. 7417, pp. S4-S6, 2012.

[40] G. G. Brusselle, G. F. Joos, and K. R. Bracke, "New insights into the immunology of chronic obstructive pulmonary disease," The Lancet, vol. 378, no. 9795, pp. 1015-1026, 2011.

[41] A. Emmendoerffer, M. Hecht, T. Boeker, M. Mueller, and U. Heinrich, "Role of inflammation in chemical-induced lung cancer," Toxicology Letters, vol. 112-113, pp. 185-191, 2000.

[42] E. A. Engels, "Inflammation in the development of lung cancer: epidemiological evidence," Expert Review of Anticancer Therapy, vol. 8, no. 4, pp. 605-615, 2008.

[43] S. D. Shapiro and E. P. Ingenito, "The pathogenesis of chronic obstructive pulmonary disease: advances in the past 100 years," American Journal of Respiratory Cell and Molecular Biology, vol. 32, no. 5, pp. 367-372, 2005.

[44] R. Medzhitov, "Origin and physiological roles of inflammation," Nature, vol. 454, no. 7203, pp. 428-435, 2008.

[45] E. M. Drost, K. M. Skwarski, J. Sauleda et al., "Oxidative stress and airway inflammation in severe exacerbations of COPD," Thorax, vol. 60, no. 4, pp. 293-300, 2005.

[46] A. Federico, F. Morgillo, C. Tuccillo, F. Ciardiello, and C. Loguercio, "Chronic inflammation and oxidative stress in human carcinogenesis," International Journal of Cancer, vol. 121, no. 11, pp. 2381-2386, 2007.

[47] C. Gessner, R. Scheibe, M. Wötzel et al., "Exhaled breath condensate cytokine patterns in chronic obstructive pulmonary disease," Respiratory Medicine, vol. 99, no. 10, pp. 1229-1240, 2005.

[48] L. J. Marnett, "Oxyradicals and DNA damage," Carcinogenesis, vol. 21, no. 3, pp. 361-370, 2000.

[49] V. L. Kinnula, "Focus on antioxidant enzymes and antioxidant strategies in smoking related airway diseases," Thorax, vol. 60, no. 8, pp. 693-700, 2005.

[50] C. B. Gilks, K. Price, J. L. Wright, and A. Churg, "Antioxidant gene expression in rat lung after exposure to cigarette smoke," American Journal of Pathology, vol. 152, no. 1, pp. 269-278, 1998.

[51] K. McCusker and J. Hoidal, "Selective increase of antioxidant enzyme activity in the alveolar macrophages from cigarette smokers and smoke-exposed hamsters," American Review of Respiratory Disease, vol. 141, no. 3, pp. 678-682, 1990.

[52] I. Rahman and W. MacNee, "Oxidant/antioxidant imbalance in smokers and chronic obstructive pulmonary disease," Thorax, vol. 51, no. 4, pp. 348-350, 1996. 
[53] F. Balkwill and A. Mantovani, "Cancer and inflammation: implications for pharmacology and therapeutics," Clinical Pharmacology and Therapeutics, vol. 87, no. 4, pp. 401-406, 2010.

[54] L. M. Coussens and Z. Werb, "Inflammation and cancer," Nature, vol. 420, no. 6917, pp. 860-867, 2002.

[55] C. Porta, P. Larghi, M. Rimoldi et al., "Cellular and molecular pathways linking inflammation and cancer," Immunobiology, vol. 214, no. 9-10, pp. 761-777, 2009.

[56] D. I. Feig, T. M. Reid, and L. A. Loeb, "Reactive oxygen species in tumorigenesis," Cancer Research, vol. 54, no. 7, supplement, pp. 1890s-1894s, 1994.

[57] J. E. Klaunig and L. M. Kamendulis, "The role of oxidative stress in carcinogenesis," Annual Review of Pharmacology and Toxicology, vol. 44, pp. 239-267, 2004.

[58] N. Azad, Y. Rojanasakul, and V. Vallyathan, "Inflammation and lung cancer: roles of reactive oxygen/nitrogen species," Journal of Toxicology and Environmental Health B, vol. 11, no. 1, pp. 1-15, 2008.

[59] C. Szabó and H. Ohshima, "DNA damage induced by peroxynitrite: subsequent biological effects," Nitric Oxide, vol. 1, no. 5, pp. 373-385, 1997.

[60] S. A. Belinsky, "Role of the cytosine DNA-methyltransferase and p16(INK4a) genes in the development of mouse lung tumors," Experimental Lung Research, vol. 24, no. 4, pp. 463-479, 1998.

[61] W. P. Bennett, T. V. Colby, W. D. Travis et al., "p53 Protein accumulates frequently in early bronchial neoplasia," Cancer Research, vol. 53, no. 20, pp. 4817-4822, 1993.

[62] S. S. Hecht, "Cigarette smoking and lung cancer: chemical mechanisms and approaches to prevention," Lancet Oncology, vol. 3, no. 8, pp. 461-469, 2002.

[63] M. Volm, G. Van Kaick, and J. Mattern, "Analysis of c-fos, c-jun, c-erbB1, c-erbB2 and c-myc in primary lung carcinomas and their lymph node metastases," Clinical and Experimental Metastasis, vol. 12, no. 4, pp. 329-334, 1994.

[64] S. Dubey and C. A. Powell, "Update in lung cancer 2007," American Journal of Respiratory and Critical Care Medicine, vol. 177, no. 9, pp. 941-946, 2008.

[65] S. S. Hecht, "Lung carcinogenesis by tobacco smoke," International Journal of Cancer, vol. 131, no. 12, pp. 2724-2732, 2012.

[66] P. O'Reilly and W. Bailey, "Clinical use of exhaled biomarkers in COPD," International Journal of COPD, vol. 2, no. 4, pp. 403408, 2007.

[67] G. M. Mutlu, K. W. Garey, R. A. Robbins, L. H. Danziger, and I. Rubinstein, "Collection and analysis of exhaled breath condensate in humans," American Journal of Respiratory and Critical Care Medicine, vol. 164, no. 5, pp. 731-737, 2001.

[68] Z. L. Borrill, K. Roy, and D. Singh, "Exhaled breath condensate biomarkers in COPD," European Respiratory Journal, vol. 32, no. 2, pp. 472-486, 2008.

[69] H. P. Chan, C. Lewis, and P. S. Thomas, "Exhaled breath analysis: novel approach for early detection of lung cancer," Lung Cancer, vol. 63, no. 2, pp. 164-168, 2009.

[70] S. S. Y. Ai, K. Hsu, C. Herbert et al., "Mitochondrial DNA mutations in exhaled breath condensate of patients with lung cancer," Respiratory Medicine, vol. 107, no. 6, pp. 911-918, 2013.

[71] I. Horváth, J. Hunt, P. J. Barnes et al., "Exhaled breath condensate: methodological recommendations and unresolved questions," European Respiratory Journal, vol. 26, no. 3, pp. 523-548, 2005.

[72] S. A. Kharitonov and P. J. Barnes, "Biomarkers of some pulmonary diseases in exhaled breath," Biomarkers, vol. 7, no. 1, pp. $1-32,2002$.
[73] P. P. Rosias, C. M. Robroeks, H. J. Niemarkt et al., "Breath condenser coatings affect measurement of biomarkers in exhaled breath condensate," European Respiratory Journal, vol. 28, no. 5, pp. 1036-1041, 2006.

[74] E. Baraldi, L. Ghiro, V. Piovan, S. Carraro, F. Zacchello, and S. Zanconato, "Safety and success of exhaled breath condensate collection in asthma," Archives of Disease in Childhood, vol. 88, no. 4, pp. 358-360, 2003.

[75] I. Korovesi, E. Papadomichelakis, S. E. Orfanos et al., "Exhaled breath condensate in mechanically ventilated brain-injured patients with no lung injury or sepsis," Anesthesiology, vol. 114, no. 5, pp. 1118-1129, 2011.

[76] P. P. R. Rosias, C. M. Robroeks, K. D. van de Kant et al., "Feasibility of a new method to collect exhaled breath condensate in pre-school children," Pediatric Allergy and Immunology, vol. 21, no. 1, pp. e235-244, 2010.

[77] O. Holz, "Catching breath: monitoring airway inflammation using exhaled breath condensate," European Respiratory Journal, vol. 26, no. 3, pp. 371-372, 2005.

[78] P. Montuschi, "Analysis of exhaled breath condensate in respiratory medicine: methodological aspects and potential clinical applications," Therapeutic Advances in Respiratory Disease, vol. 1, no. 1, pp. 5-23, 2007.

[79] P. Montuschi, "Indirect monitoring of lung inflammation," Nature Reviews Drug Discovery, vol. 1, no. 3, pp. 238-242, 2002.

[80] R. M. Effros, M. B. Dunning III, J. Biller, and R. Shaker, "The promise and perils of exhaled breath condensates," American Journal of Physiology. Lung Cellular and Molecular Physiology, vol. 287, no. 6, pp. L1073-L1080, 2004.

[81] Y. Liang, S. M. Yeligar, and L. A. S. Brown, "Exhaled breath condensate: a promising source for biomarkers of lung disease," The Scientific World Journal, vol. 2012, Article ID 217518, 7 pages, 2012.

[82] A. Bikov, G. Galffy, L. Tamasi, Z. Lazar, G. Losonczy, and I. Horvath, "Exhaled breath condensate $\mathrm{pH}$ is influenced by respiratory droplet dilution," Journal of Breath Research, vol. 6, no. 4, Article ID 046002, 2012.

[83] S. Chow, D. H. Yates, and P. S. Thomas, "Reproducibility of exhaled breath condensate markers," European Respiratory Journal, vol. 32, no. 4, pp. 1124-1126, 2008.

[84] T. Okano, T. Kondo, T. Kakisaka et al., "Plasma proteomics of lung cancer by a linkage of multi-dimensional liquid chromatography and two-dimensional difference gel electrophoresis," Proteomics, vol. 6, no. 13, pp. 3938-3948, 2006.

[85] W.-M. Gao, R. Kuick, R. P. Orchekowski et al., "Distinctive serum protein profiles involving abundant proteins in lung cancer patients based upon antibody microarray analysis," $B M C$ Cancer, vol. 5, article 110, 2005.

[86] A. M. Rodríguez-Piñeiro, S. Blanco-Prieto, N. Sánchez-Otero, F. J. Rodríguez-Berrocal, and M. P. de la Cadena, "On the identification of biomarkers for non-small cell lung cancer in serum and pleural effusion," Journal of Proteomics, vol. 73, no. 8, pp. 1511-1522, 2010.

[87] I. Salama, P. S. Malone, F. Mihaimeed, and J. L. Jones, "A review of the S100 proteins in cancer," European Journal of Surgical Oncology, vol. 34, no. 4, pp. 357-364, 2008.

[88] T. Vogl, A. L. Gharibyan, and L. A. Morozova-Roche, "Proinflammatory S100A8 and S100A9 proteins: self-assembly into multifunctional native and amyloid complexes," International Journal of Molecular Sciences, vol. 13, no. 3, pp. 2893-2917, 2012. 
[89] K. Hsu, C. Champaiboon, B. D. Guenther et al., "Anti-infective protective properties of S100 calgranulins," Anti-Inflammatory and Anti-Allergy Agents in Medicinal Chemistry, vol. 8, no. 4, pp. 290-305, 2009.

[90] I. Marenholz, C. W. Heizmann, and G. Fritz, "S100 proteins in mouse and man: from evolution to function and pathology (including an update of the nomenclature)," Biochemical and Biophysical Research Communications, vol. 322, no. 4, pp. 11111122, 2004.

[91] J. Goyette and C. L. Geczy, "Inflammation-associated S100 proteins: new mechanisms that regulate function," Amino Acids, vol. 41, no. 4, pp. 821-842, 2011.

[92] B. W. Schafer, R. Wicki, D. Engelkamp, M.-G. Mattei, and C. W. Heizmann, "Isolation of a YAC clone covering a cluster of nine S100 genes on human chromosome 1q21: rationale for a new nomenclature of the S100 calcium- binding protein family," Genomics, vol. 25, no. 3, pp. 638-643, 1995.

[93] D. Foell, H. Wittkowski, T. Vogl, and J. Roth, "S100 proteins expressed in phagocytes: a novel group of damage-associated molecular pattern molecules," Journal of Leukocyte Biology, vol. 81, no. 1, pp. 28-37, 2007.

[94] R. J. Passey, K. Xu, D. A. Hume, and C. L. Geczy, "S100A8: emerging functions and regulation," Journal of Leukocyte Biology, vol. 66, no. 4, pp. 549-556, 1999.

[95] C. Kerkhoff, M. Klempt, and C. Sorg, "Novel insights into structure and function of MRP8 (S100A8) and MRP14 (S100A9)," Biochimica et Biophysica Acta, vol. 1448, no. 2, pp. 200-211, 1998.

[96] J. Roth, T. Vogl, C. Sorg, and C. Sunderkötter, "Phagocytespecific S100 proteins: a novel group of proinflammatory molecules," Trends in Immunology, vol. 24, no. 4, pp. 155-158, 2003.

[97] C. Gebhardt, J. Németh, P. Angel, and J. Hess, "S100A8 and S100A9 in inflammation and cancer," Biochemical Pharmacology, vol. 72, no. 11, pp. 1622-1631, 2006.

[98] S. Y. Lim, M. J. Raftery, and C. L. Geczy, "Oxidative modifications of DAMPs suppress inflammation: the case for S100A8 and S100A9," Antioxidants and Redox Signaling, vol. 15, no. 8, pp. 2235-2248, 2011.

[99] Y. L. Su, M. J. Raftery, J. Goyette, K. Hsu, and C. L. Geczy, “Oxidative modifications of S100 proteins: functional regulation by redox," Journal of Leukocyte Biology, vol. 86, no. 3, pp. 577-587, 2009.

[100] P. Rouleau, K. Vandal, C. Ryckman et al., "The calcium-binding protein S100A12 induces neutrophil adhesion, migration, and release from bone marrow in mouse at concentrations similar to those found in human inflammatory arthritis," Clinical Immunology, vol. 107, no. 1, pp. 46-54, 2003.

[101] C. Ryckman, K. Vandal, P. Rouleau, M. Talbot, and P. A. Tessier, "Proinflammatory activities of S100: proteins S100A8, S100A9, and S100A8/A9 induce neutrophil chemotaxis and adhesion," Journal of Immunology, vol. 170, no. 6, pp. 3233-3242, 2003.

[102] Z. Yang, T. Tao, M. J. Raftery, P. Youssef, N. Di Girolamo, and C. L. Geczy, "Proinflammatory properties of the human S100 protein S100A12," Journal of Leukocyte Biology, vol. 69, no. 6, pp. 986-994, 2001.

[103] M. A. Hofmann, S. Drury, C. Fu et al., "RAGE mediates a novel proinflammatory axis: a central cell surface receptor for S100/ calgranulin polypeptides," Cell, vol. 97, no. 7, pp. 889-901, 1999.

[104] H.-L. Hsieh, B. W. Schäfer, N. Sasaki, and C. W. Heizmann, "Expression analysis of S100 proteins and RAGE in human tumors using tissue microarrays," Biochemical and Biophysical Research Communications, vol. 307, no. 2, pp. 375-381, 2003.
[105] D. Foell and J. Roth, "Proinflammatory S100 proteins in arthritis and autoimmune disease," Arthritis and Rheumatism, vol. 50, no. 12, pp. 3762-3771, 2004.

[106] C. W. Heizmann, G. Fritz, and B. W. Schäfer, "S100 proteins: structure, functions and pathology," Frontiers in Bioscience, vol. 7, pp. 1356-1368, 2002.

[107] D. Foell, T. Kucharzik, M. Kraft et al., "Neutrophil derived human S100A12 (EN-RAGE) is strongly expressed during chronic active inflammatory bowel disease," Gut, vol. 52, no. 6, pp. 847-853, 2003.

[108] D. Merkel, W. Rist, P. Seither, A. Weith, and M. C. Lenter, "Proteomic study of human bronchoalveolar lavage fluids from smokers with chronic obstructive pulmonary disease by combining surface-enhanced laser desorption/ionization-mass spectrometry profiling with mass spectrometric protein identification," Proteomics, vol. 5, no. 11, pp. 2972-2980, 2005.

[109] E. Lorenz, M. S. Muhlebach, P. A. Tessier et al., "Different expression ratio of S100A8/A9 and S100A12 in acute and chronic lung diseases," Respiratory Medicine, vol. 102, no. 4, pp. 567-573, 2008.

[110] G. Srikrishna, "S100A8 and S100A9: new insights into their roles in malignancy," Journal of Innate Immunity, vol. 4, no. 1, pp. 3140, 2011.

[111] T. Vogl, C. Pröpper, M. Hartmann et al., "S100A12 is expressed exclusively by granulocytes and acts independently from MRP8 and MRP14," Journal of Biological Chemistry, vol. 274, no. 36, pp. 25291-25296, 1999.

[112] G. Srikrishna and H. H. Freeze, "Endogenous damage-associated molecular pattern molecules at the crossroads of inflammation and cancer," Neoplasia, vol. 11, no. 7, pp. 615-628, 2009.

[113] M. K. Srivastava, Å. Andersson, L. Zhu et al., "Myeloid suppressor cells and immune modulation in lung cancer," Immunotherapy, vol. 4, no. 3, pp. 291-304, 2012.

[114] R. Donato, "S100: a multigenic family of calcium-modulated proteins of the EF-hand type with intracellular and extracellular functional roles," International Journal of Biochemistry and Cell Biology, vol. 33, no. 7, pp. 637-668, 2001.

[115] D. I. Gabrilovich and S. Nagaraj, "Myeloid-derived suppressor cells as regulators of the immune system," Nature Reviews Immunology, vol. 9, no. 3, pp. 162-174, 2009.

[116] P. H. Feng, K. Y. Lee, Y. L. Chang et al., "CD14 ${ }^{+} \mathrm{S} 100 \mathrm{~A} 9^{+}$monocytic myeloid-derived suppressor cells and their clinical relevance in non-small cell lung cancer," American Journal of Respiratory \& Critical Care Medicine, vol. 186, no. 10, pp. 1025-1036, 2012.

[117] P. Sinha, C. Okoro, D. Foell, H. H. Freeze, S. Ostrand-Rosenberg, and G. Srikrishna, "Proinflammatory S100 proteins regulate the accumulation of myeloid-derived suppressor cells," Journal of Immunology, vol. 181, no. 7, pp. 4666-4675, 2008.

[118] S. Nagaraj and D. I. Gabrilovich, "Myeloid-derived suppressor cells in human cancer," Cancer Journal, vol. 16, no. 4, pp. 348353,2010

[119] L. Dolcetti, I. Marigo, B. Mantelli, E. Peranzoni, P. Zanovello, and V. Bronte, "Myeloid-derived suppressor cell role in tumorrelated inflammation," Cancer Letters, vol. 267, no. 2, pp. 216225, 2008.

[120] P. Serafini, I. Borrello, and V. Bronte, "Myeloid suppressor cells in cancer: recruitment, phenotype, properties, and mechanisms of immune suppression," Seminars in Cancer Biology, vol. 16, no. 1, pp. 53-65, 2006.

[121] S. Ostrand-Rosenberg, "Cancer and complement," Nature Biotechnology, vol. 26, no. 12, pp. 1348-1349, 2008. 
[122] G. Zwadlo, J. Bruggen, G. Gerhards, R. Schlegel, and C. Sorg, "Two calcium-binding proteins associated with specific stages of myeloid cell differentiation are expressed by subsets of macrophages in inflammatory tissues," Clinical and Experimental Immunology, vol. 72, no. 3, pp. 510-515, 1988.

[123] K. Odink, N. Cerletti, J. Bruggen et al., "Two calcium-binding proteins in infiltrate macrophages of rheumatoid arthritis," Nature, vol. 330, no. 6143, pp. 80-82, 1987.

[124] A. Hermani, B. De Servi, S. Medunjanin, P. A. Tessier, and D. Mayer, "S100A8 and S100A9 activate MAP kinase and NF- $\kappa$ B signaling pathways and trigger translocation of RAGE in human prostate cancer cells," Experimental Cell Research, vol. 312, no. 2, pp. 184-197, 2006.

[125] A. Hermani, J. Hess, B. De Servi et al., "Calcium-binding proteins S100A8 and S100A9 as novel diagnostic markers in human prostate cancer," Clinical Cancer Research, vol. 11, no. 14, pp. 5146-5152, 2005.

[126] H.-Y. Yong and A. Moon, "Roles of calcium-binding proteins, S100A8 and S100A9, in invasive phenotype of human gastric cancer cells," Archives of Pharmacal Research, vol. 30, no. 1, pp. 75-81, 2007.

[127] J. Stuli'k, J. Osterreicher, K. Koupilova' et al., “The analysis of S100A9 and S100A8 expression in matched sets of macroscopically normal colon mucosa and colorectal carcinoma: the S100A9 and S100A8 positive cells underlie and invade tumor mass," Electrophoresis, vol. 20, no. 4-5, pp. 41047-41554, 1999.

[128] H.-J. Kim, H. J. Kang, H. Lee et al., "Identification of S100A8 and S100A9 as serological markers for colorectal cancer," Journal of Proteome Research, vol. 8, no. 3, pp. 1368-1379, 2009.

[129] H. Kawai, Y. Minamiya, and N. Takahashi, "Prognostic impact of S100A9 overexpression in non-small cell lung cancer," Tumor Biology, vol. 32, no. 4, pp. 641-646, 2011.

[130] K. Arai, "Immunohistochemical investigation of S100A9 expression in pulmonary adenocarcinoma: S100A9 expression is associated with tumor differentiation," Oncology Reports, vol. 8, no. 3, pp. 591-596, 2001.

[131] S. Rafii and D. Lyden, "S100 chemokines mediate bookmarking of premetastatic niches," Nature Cell Biology, vol. 8, no. 12, pp. 1321-1323, 2006.

[132] S. Hiratsuka, A. Watanabe, H. Aburatani, and Y. Maru, "Tumour-mediated upregulation of chemoattractants and recruitment of myeloid cells predetermines lung metastasis," Nature Cell Biology, vol. 8, no. 12, pp. 1369-1375, 2006.

[133] S. Hiratsuka, A. Watanabe, Y. Sakurai et al., "The S100A8serum amyloid A3-TLR4 paracrine cascade establishes a premetastatic phase," Nature Cell Biology, vol. 10, no. 11, pp. 13491355, 2008.

[134] S. Kwiatkowska, K. Noweta, M. Zieba, D. Nowak, and P. Bialasiewicz, "Enhanced exhalation of matrix metalloproteinase9 and tissue inhibitor of metalloproteinase-1 in patients with COPD exacerbation: a prospective study," Respiration, vol. 84, no. 3, pp. 231-241, 2012.

[135] H. P. Chan, V. Tran, C. Lewis, and P. S. Thomas, "Elevated levels of oxidative stress markers in exhaled breath condensate," Journal of Thoracic Oncology, vol. 4, no. 2, pp. 172-178, 2009.

[136] P. N. R. Dekhuijzen, K. K. H. Aben, I. Dekker et al., "Increased exhalation of hydrogen peroxide in patients with stable and unstable chronic obstructive pulmonary disease," American Journal of Respiratory and Critical Care Medicine, vol. 154, no. 3, pp. 813-816, 1996.
[137] H. Inonu, S. Doruk, S. Sahin et al., "Oxidative stress levels in exhaled breath condensate associated with COPD and smoking," Respiratory Care, vol. 57, no. 3, pp. 413-419, 2012.

[138] D. Nowak, M. Kasielski, A. Antczak, T. Pietras, and P. Bialasiewicz, "Increased content of thiobarbituric acid-reactive substances and hydrogen peroxide in the expired breath condensate of patients with stable chronic obstructive pulmonary disease: no significant effect of cigarette smoking," Respiratory Medicine, vol. 93, no. 6, pp. 389-396, 1999.

[139] M. Corradi, M. Majori, G. C. Cacciani, G. F. Consigli, E. De'Munari, and A. Pesci, "Increased exhaled nitric oxide in patients with stable chronic obstructive pulmonary disease," Thorax, vol. 54, no. 7, pp. 572-575, 1999.

[140] C.-Y. Liu, C.-H. Wang, T.-C. Chen, H.-C. Lin, C.-T. Yu, and H.-P. Kuo, "Increased level of exhaled nitric oxide and up-regulation of inducible nitric oxide synthase in patients with primary lung cancer," British Journal of Cancer, vol. 78, no. 4, pp. 534-541, 1998.

[141] J. Liu, A. Sandrini, M. C. Thurston, D. H. Yates, and P. S. Thomas, "Nitric oxide and exhaled breath nitrite/nitrates in chronic obstructive pulmonary disease patients," Respiration, vol. 74, no. 6, pp. 617-623, 2007.

[142] F. A. Masri, S. A. A. Comhair, T. Koeck et al., "Abnormalities in nitric oxide and its derivatives in lung cancer," American Journal of Respiratory and Critical Care Medicine, vol. 172, no. 5, pp. 597605, 2005.

[143] W. Maziak, S. Loukides, S. Culpitt, P. Sullivan, S. A. Kharitonov, and P. J. Barnes, "Exhaled nitric oxide in chronic obstructive pulmonary disease," American Journal of Respiratory and Critical Care Medicine, vol. 157, no. 3, pp. 998-1002, 1998.

[144] P. Montuschi, S. A. Kharitonov, and P. J. Barnes, "Exhaled carbon monoxide and nitric oxide in COPD," Chest, vol. 120, no. 2, pp. 496-501, 2001.

[145] C. Gessner, S. Hammerschmidt, H. Kuhn et al., "Breath condensate nitrite correlates with hyperinflation in chronic obstructive pulmonary disease," Respiratory Medicine, vol. 101, no. 11, pp. 2271-2278, 2007.

[146] V. Rihák, P. Zatloukal, J. Chládková, A. Zimulová, Z. Havlínová, and J. Chládek, "Nitrite in exhaled breath condensate as a marker of nitrossative stress in the airways of patients with asthma, COPD, and idiopathic pulmonary fibrosis," Journal of Clinical Laboratory Analysis, vol. 24, no. 5, pp. 317-322, 2010.

[147] M. Corradi, A. Pesci, R. Casana et al., "Nitrate in exhaled breath condensate of patients with different airway diseases," Nitric Oxide, vol. 8, no. 1, pp. 26-30, 2003.

[148] C. Brindicci, K. Ito, O. Torre, P. J. Barnes, and S. A. Kharitonov, "Effects of aminoguanidine, an inhibitor of inducible nitric oxide synthase, on nitric oxide production and its metabolites in healthy control subjects, healthy smokers, and COPD patients," Chest, vol. 135, no. 2, pp. 353-367, 2009.

[149] G. O. Osoata, T. Hanazawa, C. Brindicci et al., "Peroxynitrite elevation in exhaled breath condensate of COPD and its inhibition by fudosteine," Chest, vol. 135, no. 6, pp. 1513-1520, 2009.

[150] P. Montuschi, J. V. Collins, G. Ciabattoni et al., "Exhaled 8isoprostane as an in vivo biomarker of lung oxidative stress in patients with COPD and healthy smokers," American Journal of Respiratory and Critical Care Medicine, vol. 162, no. 3, pp. 1175$1177,2000$.

[151] F. W. S. Ko, C. Y. K. Lau, T. F. Leung, G. W. K. Wong, C. W. K. Lam, and D. S. C. Hui, "Exhaled breath condensate levels of 8 -isoprostane, growth related oncogene $\alpha$ and monocyte 
chemoattractant protein-1 in patients with chronic obstructive pulmonary disease," Respiratory Medicine, vol. 100, no. 4, pp. 630-638, 2006.

[152] E. Dalaveris, T. Kerenidi, A. Katsabeki-Katsafli et al., "VEGF, TNF- $\alpha$ and 8-isoprostane levels in exhaled breath condensate and serum of patients with lung cancer," Lung Cancer, vol. 64, no. 2, pp. 219-225, 2009.

[153] M. Corradi, I. Rubinstein, R. Andreoli et al., "Aldehydes in exhaled breath condensate of patients with chronic obstructive pulmonary disease," American Journal of Respiratory and Critical Care Medicine, vol. 167, no. 10, pp. 1380-1386, 2003.

[154] A. Gönenç, Y. Özkan, M. Torun, and B. Şmşek, "Plasma malondialdehyde (MDA) levels in breast and lung cancer patients," Journal of Clinical Pharmacy and Therapeutics, vol. 26, no. 2, pp. 141-144, 2001.

[155] H. Ahmadzai, S. Huang, R. Hettiarachchi, J. L. Lin, P. S. Thomas, and Q. Zhang, "Exhaled breath condensate: a comprehensive update," Clinical Chemistry and Laboratory Medicine, pp. 13431361, 2013.

[156] G. E. Carpagnano, G. P. Palladino, D. Lacedonia, A. Koutelou, S. Orlando, and M. P. Foschino-Barbaro, "Neutrophilic airways inflammation in lung cancer: the role of exhaled LTB-4 and IL8," BMC Cancer, vol. 11, article 226, 2011.

[157] J.-L. Corhay, M. Henket, D. Nguyen, B. Duysinx, J. Sele, and R. Louis, "Leukotriene B4 contributes to exhaled breath condensate and sputum neutrophil chemotaxis in COPD," Chest, vol. 136, no. 4, pp. 1047-1054, 2009.

[158] P. Montuschi, S. A. Kharitonov, G. Ciabattoni, and P. J. Barnes, "Exhaled leukotrienes and prostaglandins in COPD," Thorax, vol. 58, no. 7, pp. 585-588, 2003.

[159] K. Kostikas, M. Gaga, G. Papatheodorou, T. Karamanis, D. Orphanidou, and S. Loukides, "Leukotriene B4 in exhaled breath condensate and sputum supernatant in patients with COPD and asthma," Chest, vol. 127, no. 5, pp. 1553-1559, 2005.

[160] A. Antczak, W. Piotrowski, J. Marczak, M. Ciebiada, P. Gorski, and P. J. Barnes, "Correlation between eicosanoids in bronchoalveolar lavage fluid and in exhaled breath condensate," Disease Markers, vol. 30, no. 5, pp. 213-220, 2011.

[161] E. Chan, T. Sivagnanam, Q. Zhang, C. R. Lewis, and P. S. Thomas, "Tumour necrosis factor alpha and oxidative stress in the breath condensate of those with non-small cell lung cancer," Journal of Cancer Therapy, vol. 3, no. 4A, pp. 460-466, 2012.

[162] E. Bucchioni, S. A. Kharitonov, L. Allegra, and P. J. Barnes, "High levels of interleukin-6 in the exhaled breath condensate of patients with COPD," Respiratory Medicine, vol. 97, no. 12, pp. 1299-1302, 2003.

[163] G. E. Carpagnano, O. Resta, M. P. Foschino-Barbaro, E. Gramiccioni, and F. Carpagnano, "Interleukin-6 is increased in breath condensate of patients with non-small cell lung cancer," International Journal of Biological Markers, vol. 17, no. 2, pp. 141-145, 2002.

[164] A.-R. Koczulla, S. Noeske, C. Herr et al., "Acute and chronic effects of smoking on inflammation markers in exhaled breath condensate in current smokers," Respiration, vol. 79, no. 1, pp. 61-67, 2009.

[165] G. E. Carpagnano, G. P. Palladino, D. Martinelli, D. Lacedonia, S. Orlando, and M. P. Foschino-Barbaro, "Exhaled matrix metalloproteinase-9 in lung cancer," Rejuvenation Research, vol. 15, no. 4, pp. 359-365, 2012.

[166] P. Carratu, C. Scoditti, M. Maniscalco et al., "Exhaled and arterial levels of endothelin-1 are increased and correlate with pulmonary systolic pressure in COPD with pulmonary hypertension," BMC Pulmonary Medicine, vol. 8, article 20, 2008.

[167] G. E. Carpagnano, M. P. Foschino-Barbaro, O. Restaa, E. Gramiccioni, and F. Carpagnano, "Endothelin-1 is increased in the breath condensate of patients with non-small-cell lung cancer," Oncology, vol. 66, no. 3, pp. 180-184, 2004.

[168] L. Chen, H.-L. Zhu, and X. Zhang, "Clinical significance of measuring endothelin-1 in exhaled breath condensate of patients with non-small cell lung cancer," Journal of Xian Jiaotong University, vol. 32, no. 4, pp. 458-461, 2011.

[169] P. Paredi, S. A. Kharitonov, D. Leak, S. Ward, D. Cramer, and P. J. Barnes, "Exhaled ethane, a marker of lipid peroxidation, is elevated chronic obstructive pulmonary disease," American Journal of Respiratory and Critical Care Medicine, vol. 162, no. 2, pp. 369-373, 2000.

[170] M. Phillips, K. Gleeson, J. M. B. Hughes et al., "Volatile organic compounds in breath as markers of lung cancer: a cross-sectional study," Lancet, vol. 353, no. 9168, pp. 1930-1933, 1999.

[171] G. Song, T. Qin, H. Liu et al., "Quantitative breath analysis of volatile organic compounds of lung cancer patients," Lung Cancer, vol. 67, no. 2, pp. 227-231, 2010.

[172] B. Antus and I. Barta, "Exhaled breath condensate $\mathrm{pH}$ in patients with lung cancer," Lung Cancer, vol. 75, no. 2, pp. 178180, 2012.

[173] W. MacNee, S. I. Rennard, J. F. Hunt et al., "Evaluation of exhaled breath condensate $\mathrm{pH}$ as a biomarker for COPD," Respiratory Medicine, vol. 105, no. 7, pp. 1037-1045, 2011.

[174] K. Kostikas, G. Papatheodorou, K. Ganas, K. Psathakis, P. Panagou, and S. Loukides, " $\mathrm{pH}$ in expired breath condensate of patients with inflammatory airway diseases," American Journal of Respiratory and Critical Care Medicine, vol. 165, no. 10, pp. 1364-1370, 2002.

[175] W. Lee, H. Loo, and P. S. Thomas, "Airway antioxidant capacity and $\mathrm{pH}$ in chronic obstructive pulmonary disease," Oxidants and Antioxidants in Medical Science, vol. 1, no. 3, pp. 153-160, 2012.

[176] G. E. Carpagnano, M. P. Foschino-Barbaro, G. Mulé et al., “3p microsatellite alterations in exhaled breath condensate from patients with non-small cell lung cancer," American Journal of Respiratory and Critical Care Medicine, vol. 172, no. 6, pp. 738744, 2005.

[177] C. Gessner, H. Kuhn, K. Toepfer, S. Hammerschmidt, J. Schauer, and $\mathrm{H}$. Wirtz, "Detection of p53 gene mutations in exhaled breath condensate of non-small cell lung cancer patients," Lung Cancer, vol. 43, no. 2, pp. 215-222, 2004.

[178] C. Gessner, "Nachweis von mutationen des K-ras-Cens im atemkondensat von patienten mit nicht-kleinzelligem lungenkarzinom (NSCLC) als mögliche nicht-invasive screeningmethode," Pneumologie, vol. 52, no. 7, pp. 426-427, 1998.

[179] D. Zhang, N. Takigawa, N. Ochi et al., "Detection of the EGFR mutation in exhaled breath condensate from a heavy smoker with squamous cell carcinoma of the lung," Lung Cancer, vol. 73, no. 3, pp. 379-380, 2011.

[180] W. Han, T. Wang, A. A. Reilly, S. M. Keller, and S. D. Spivack, "Gene promoter methylation assayed in exhaled breath, with differences in smokers and lung cancer patients," Respiratory Research, vol. 10, article 86, 2009.

[181] G. E. Carpagnano, A. Koutelou, M. I. Natalicchio et al., "HPV in exhaled breath condensate of lung cancer patients," British Journal of Cancer, vol. 105, no. 8, pp. 1183-1190, 2011. 
[182] G. E. Carpagnano, D. Lacedonia, G. P. Palladino et al., "Could exhaled ferritin and SOD be used as markers for lung cancer and prognosis prediction purposes?" European Journal of Clinical Investigation, vol. 42, no. 5, pp. 478-486, 2012. 


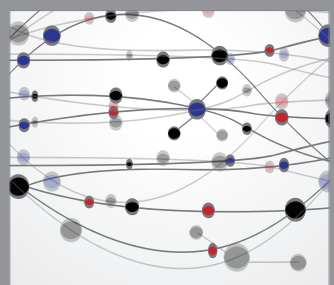

The Scientific World Journal
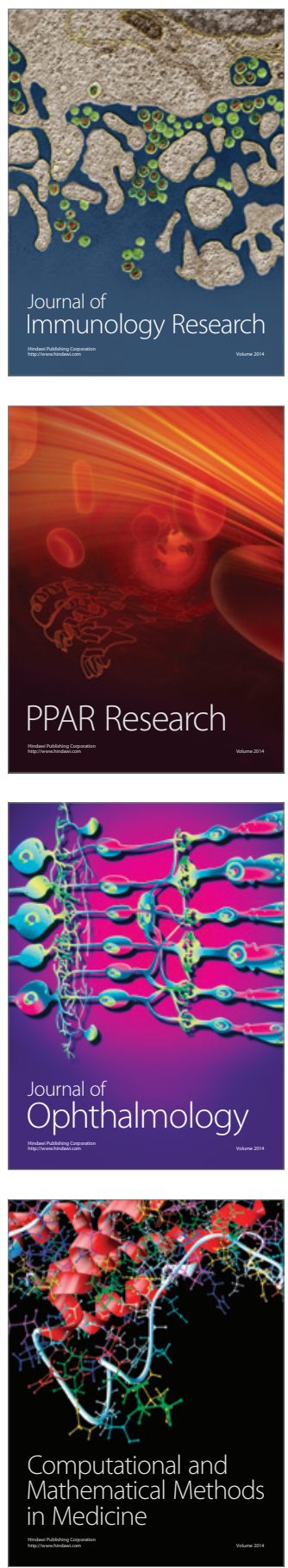

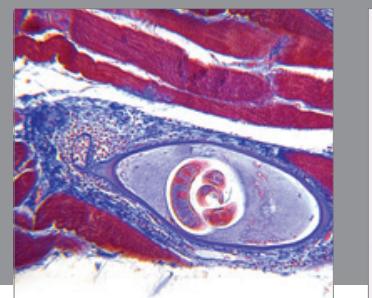

Gastroenterology

Research and Practice
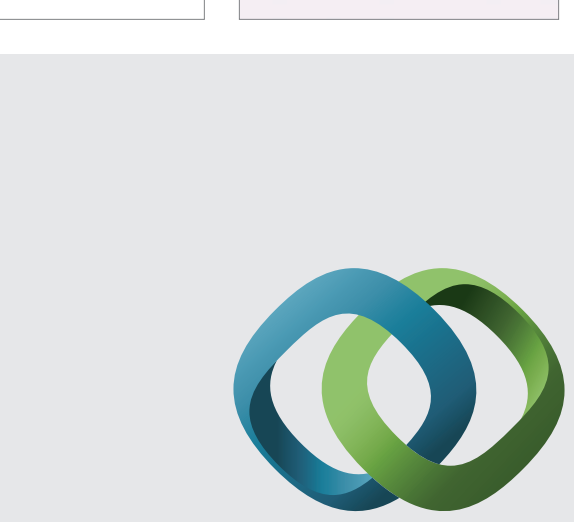

\section{Hindawi}

Submit your manuscripts at

http://www.hindawi.com
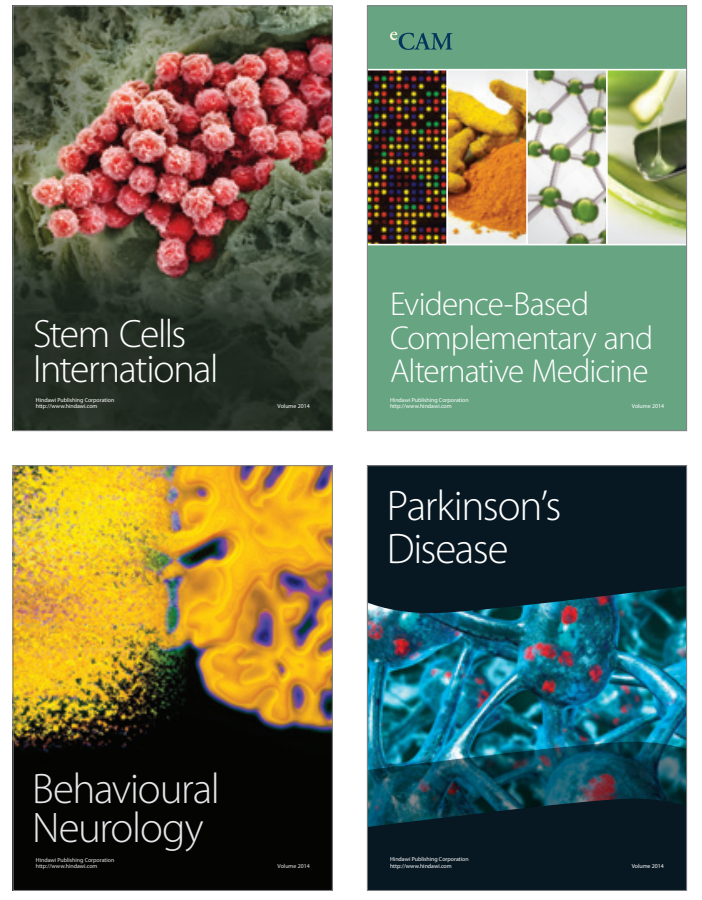
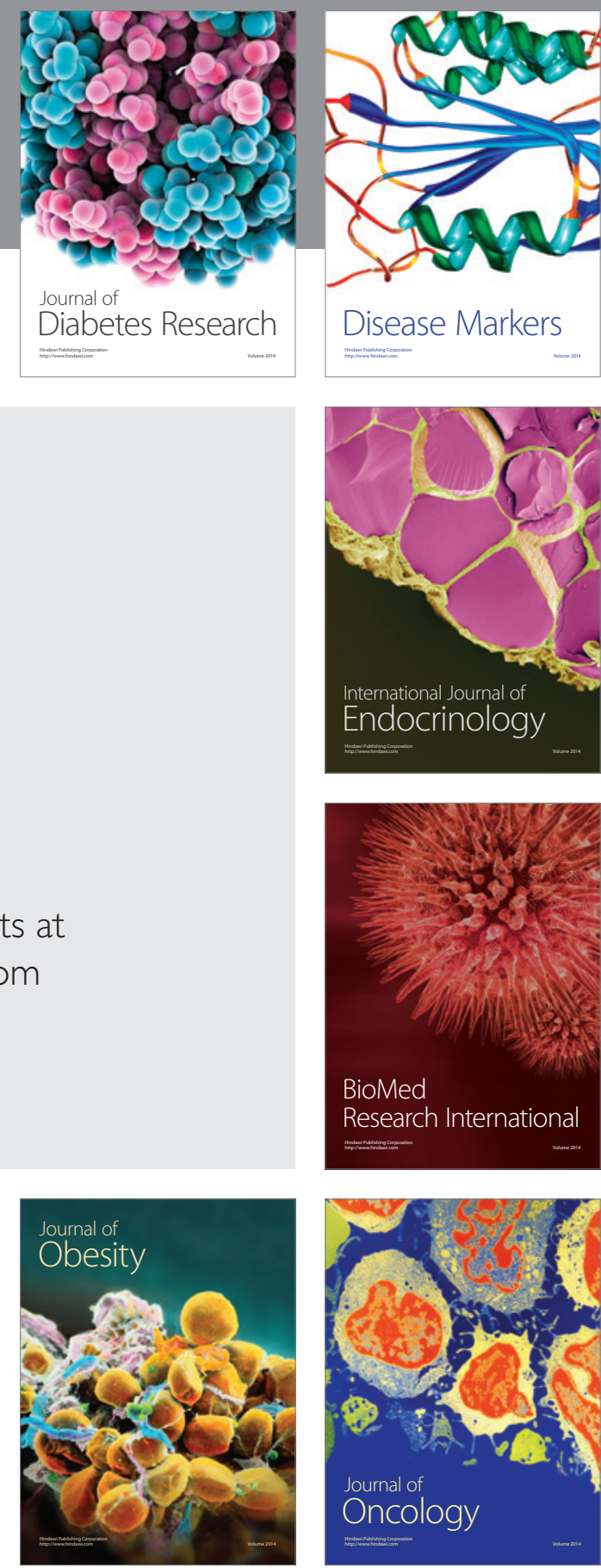

Disease Markers
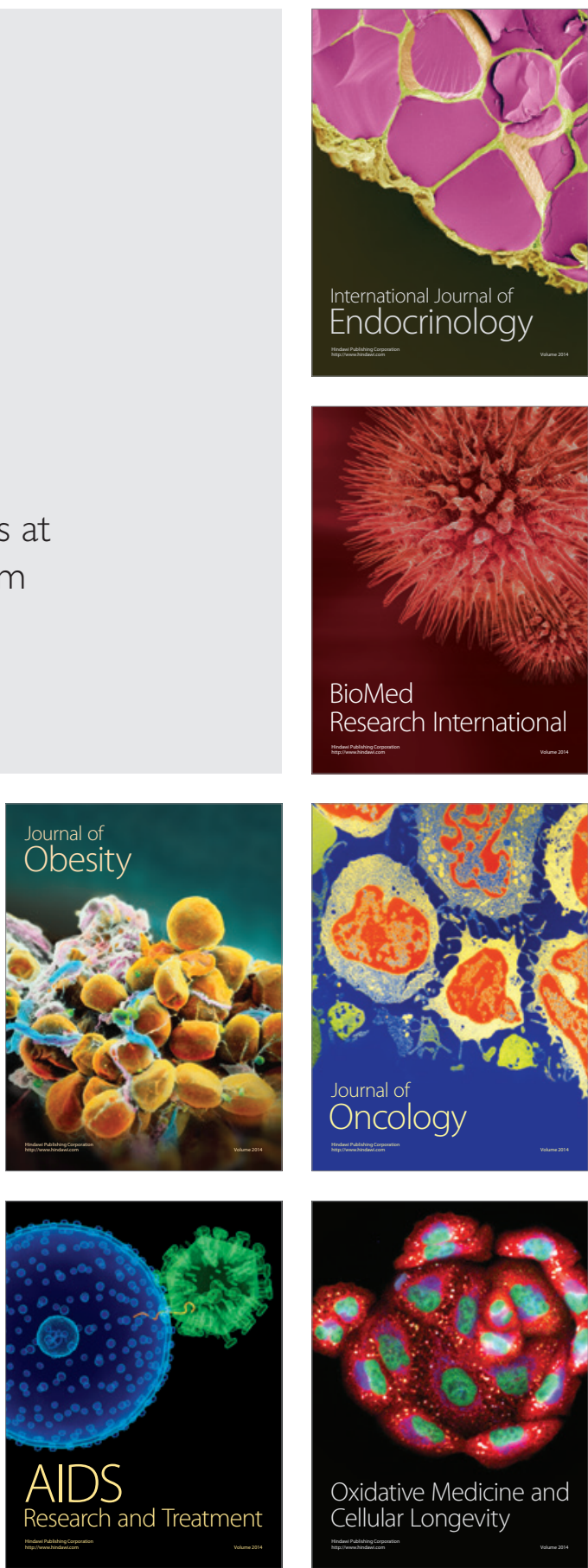